\title{
TELAAH TERHADAP KEBIJAKAN PRIVATISASI BUMN DI INDONESIA
}

\author{
Dona Pratama Jonaidi \\ Faculty of Law, University of Indonesia \\ Email :donajonaidi@gmail.com
}

\begin{abstract}
The privatization policy of state-owned enterprises (BUMN) has become prevalent in various countries throughout the world today. The main reason for the privatization is to streamline the performance of SOEs so that they can achieve their founding targets, namely the fulfillment of public services for the public and profits for the state. However, such policies often get rejection because of concerns about the lack of role of the state and the overly dominant role of the private sector that refers to a free market system so that the interests of the community are not guaranteed. This study is a normative / literature review using the statutory approach (statue approach) and conceptual approach. The purpose of this study is to provide a comprehensive understanding of the privatization policies of SOEs in Indonesia, both from the perspective of history and the positive law in force.
\end{abstract}

Keywords: Privatization, BUMN, public interest.

\begin{abstract}
ABSTRAK
Kebijakan privatisasi terhadap badan-badan usaha milik negara (BUMN) telah menjadi kelaziman di berbagai negara di seluruh dunia dewasa ini. Alasan utama dilakukannya privatisasi tersebut adalah demi mengefisienkan kinerja BUMN sehingga dapat mencapai target pendiriannya yakni pemenuhan pelayanan umum bagi masyarakat dan profit bagi negara. Akan tetapi, kebijakan demikian itu tidak jarang mendapatkan penolakan oleh karena kekhawatiran menjadi minimnya peran negara dan terlampau dominannya peran swasta yang mengacu kepada sistem pasar yang bebas sehingga kepentingan masyarakat menjadi tidak terjamin. Penelitian ini merupakan penilian normative/kepustakaan dengan menggunakan pendekatan peraturan perundang-undangan (statue approach) dan pendekatan konseptual (conceptual approach). Adapun tujuan dari penelitian ini adalah untuk memberikan pemahaman yang komprehensif perihal kebijakan privatisasi BUMN di Indonesia, baik dari perspektif sejarah maupun hukum positif yang berlaku.
\end{abstract}

Kata kunci: Privatisasi, BUMN, kepentingan umum.

\section{Pendahuluan}

Selama beberapa dekade sebelum tahun 1980-an, pemerintah di seluruh dunia meningkatkan cakupan dan tingkat aktivitas mereka untuk melakukan berbagai tugas yang telah dikerjakan oleh sektor swasta sebelumnya. Di Amerika Serikat, pemerintah federal membangun jalan raya dan bendungan, melakukan penelitian, meningkatkan otoritas pengaturnya di berbagai bidang kegiatan, dan memberi uang kepada pemerintah negara bagian dan daerah untuk mendukung fungsi mulai dari pendidikan hingga pembangunan jalan. Di Eropa Barat dan Amerika Latin, pemerintah 
menasionalisasi perusahaan, seluruh industri, bank, dan sistem perawatan kesehatan, dan di Eropa Timur, rezim komunis berusaha untuk menghilangkan sektor swasta sama sekali. ${ }^{1}$

Barulah di tahun 1980-an, gelombang ekspansi sektor publik mulai berubah di banyak belahan dunia. Di Amerika Serikat, pemerintahan Reagan mengeluarkan perintah baru: "Don't just stand there, undo something." Prinsip utama "undoing" adalah privatisasi aset dan layanan pemerintah. ${ }^{2} \mathrm{Di}$ Inggris, lebih dari 50 perusahaan (negara) dijual atau diprivatisasi dalam masa permerintahan Perdana Menteri Margareth Thatcher, termasuk puluhan industri energi dan air. ${ }^{3}$

Fenomena privatisasi juga melanda negara-negara lain di seluruh dunia sebagaimana yang dinyatakan oleh Bank Dunia berikut ini.

"Almost 7,000 enterprises have been privatized since the early 1980s. These privatizations are liquidations and sales that transfer assets to the private sector. The graph excludes reprivatizations (the return of nationalized enterprises to their former owners, which was important in Chile and Bangladesh), as well as

\footnotetext{
${ }^{1}$ Harvard Business Review, "Does Privatization Serve The Public Interest?", diunduh pada tanggal 18 Maret 2018 dari https://hbr.org/1991/11/does-privatizationserve-the-public-interest

${ }^{2}$ Ibid.

${ }^{3}$ The Telegraph, "Margaret Thatcher: one policy that led to more than 50 companies being sold or privatised", diunduh pada tanggal 18 Maret 2018 dari https://www.telegraph.co.uk/finance/comment/alistairosborne/9980292/Margaret-Thatcher-one-policy-thatled-to-more-than-50-companies-being-sold-orprivatised.html
}

management contracts, leases and the sale of minority shares. Also excluded are the sales of small retail outlets in Eastern Europe that number in the thousands and would make the graph look very different. As the graph shows, the former East Germany takes the lead with 4,500 enterprises privatized. Among developing regions, Latin America is an important privatizing region; it has sold or liquidated over 800 firms. Within that region, Mexico (433) and Chile (261) are the most active in privatization. Eastern Europe - excluding East Germany - has privatized some 805 enterprises. Africa is next (373), followed by Asia (122). "4

Pihak yang mendukung kebijakan privatisasi menyebut pergeseran dari pengelolaan oleh negara kepada swasta ialah sangat beralasan karena akan menghasilkan banyak sekali perbaikan-perbaikan yang signifikan, seperti meningkatkan efisiensi dan kualitas kinerja pemerintah yang tersisa, mengurangi pajak, dan mengecilkan ukuran pemerintahan. $^{5}$ Keyakinan tergambar dari ungkapan para penyokong privatisasi berikut ini:

"Proponents of privatization believe this is a good thing. For years, they have advanced the argument that business will always perform a given task better than government, whether it's running buses or schools, supplying healthcare or housing. The public sector is sclerotic, wasteful and undisciplined by the profit motive. The

\footnotetext{
${ }^{4}$ Mary M. Shirley. (1992). "The What, Why, and How of Privatization: A World Bank Perspective". Fordham Law Review, 60, hlm. 24. Artikel ini dapat diunduh dari http://ir.lawnet.fordham.edu/flr/vol60/iss6/2 ${ }^{5}$ Harvard Business Review, Op.Cit.
} 
private sector is dynamic, innovative and, above all, efficient." 6

Di Indonesia, gelombang privatisasi mulai terjadi setelah krisis ekonomi pada pertengahan tahun 1997. Walaupun demikian, sebenarnya privatisasi BUMN di Indonesia sudah dimulai sejak awal tahun 1990-an, tetapi privatisasi pada waktu itu baru dalam bentuk kebijakan perekonomian terhadap BUMN, berupa penjualan saham perusahaan milik negara di Pasar Bursa. ${ }^{7}$ Kebijakan pemerintah Indonesia melakukan privatisasi tersebut mendapat tanggapan beragam dari berbagai kalangan. Sebagian menganggap hal tersebut sebagai terobosan yang diperlukan untuk memperbaiki pelayanan umum di Indonesia. Akan tetapi, sebagian yang lain memandang bahwa privatisasi adalah satu langkah yang patut dikhawatirkan, terutama terhadap jaminan akan kepentingan masyarakat. Pada dasarnya kelompok terakhir memiliki ketakutan akan prinsip neoliberalisasi yang berada dibelakang kebijakan privatisasi yang diaplikasikan.

Berdasarkan pada alasan tersebutlah maka penting kiranya untuk meninjau persoalan privatisasi di Indonesia, terutama

\footnotetext{
${ }^{6}$ The Guardian, "How Privatization Could Spell The End Of Democracy”, diunduh pada tanggal 18 Maret 2018 dari

https://www.theguardian.com/technology/2017/jun/21 /privatizing-public-services-trump-democracy

${ }^{7}$ Badan Pembinaan Hukum Nasional Departemen Hukum dan HAM RI. (2005). Analisa dan Evaluasi Hukum tentang Privatisasi Badan Usaha Milik Negara (BUMN). Jakarta: BPHN RI, hlm. 17.
}

dalam kaitannya dengan konsepsi pemikiran yang dimaksud dalam Pancasila dan UndangUndang Dasar Negara Republik Indonesia Tahun 1945 bahwa "cabang-cabang produksi yang penting bagi negara dan menguasai hajat hidup orang banyak dikuasai oleh negara".

\section{Pembahasan}

\section{Seputar Privatisasi}

Sejak negara turut serta secara aktif dalam pergaulan kemasyarakataan, maka lapangan pekerjaan pemerintah makin lama makin luas. ${ }^{8}$ Oleh karenanya, kedudukan pemerintah bukan sematamata sebagai pelaksana undang-undang yang bertindak pasif tanpa inisiatif. Dalam negara hukum kesejahteraan, pemerintah bersifat aktif dan kreatif sehingga berbeda fungsi pemerintah dalam negara hukum formal yang pasif. $^{9}$ Untuk mencapai tujuan kesejahteraan umum, pemerintah memiliki kedudukuan yang bersifat rangkap dan keduanya harus dijalankan pada saat yang bersamaan, dimana kedudukan itu berkaitan satu sama lain. Pertama, di satu pihak, pemerintah berkedudukan sebagai penguasa yang berwenang membuat aturan yang harus dipatuhi oleh masyarakat supaya keteritiban dan ketentraman masyarakat

\footnotetext{
${ }^{8}$ Ridwan H.R. (2011). Hukum Administrasi Negara. Jakarta: Raja Grafindo Persada, hlm. 11.

9 Hotma P. Sibuea. (2010). Asas Negara Hukum, Peraturan Kebijakan, dan Asas-asas Umum Pemerintahan yang Baik. Jakarta: Penerbit Erlangga, hlm. 39-40.
} 
dapat diwujudkan dalam kenyataan. Kedua, di lain pihak, pemerintah berkedudukan sebagai pelayan masyarakat (public servant) yang bertugas mengurus, menyelenggarakan, melayani segenap urusan dan kepentingan masyarakat. ${ }^{10}$ Pemerintah berkedudukan bukan hanya sebagai penguasa yang berwenang mengatur, pemerintah juga berkewajiban melayani masyarakat sehingga tindakantindakannya harus dapat diterima masyarakat dan dapat merangkul semua pihak demi tercapainya tujuan negara hukum kesejahteraan.

Berdasarkan investigasinya ke banyak negara kesejahteraan, Kaufmann mengklasifikasikan persepsi dominan negara kesejahteraan sebagai berikut: ${ }^{11}$

1. A state that provides economic security and social services for certain categories (or all) og its citizens;

2. A state that takes care of a substantial redistribution of resources from the wealthier to the poor;

3. A state that has instituted social rights as a part of citizenship;

4. A state that aims at security for all and equality among its citizens;

5. A state that it is assumed explicitly responsible for the basic wellbeing of all members.

\footnotetext{
${ }^{10}$ Ridwan, Op.Cit., hlm. 42.

${ }^{11}$ Safri Nugraha. (2004). Privatisation of State Enterprises in the 20th Century: A Step Forwards or Backwards?. Jakarta: Institute For Law and Economics Studies Faculty of Law University of Indonesia, hlm. 49.
}

Karena banyaknya social-welfare activities yang ditangani oleh pemerintah dan terdapat keinginan yang kuat di pihak pemerintah untuk bertindak dengan cara monopoli dan proteksionis, Marsland berpendapat bahwa negara kesejahteraan menyebabkan bencana besar di Inggris, Amerika Serikat, dan tempat lain di seluruh dunia. Menurutnya, negara kesejahteraan menghambat dinamika persaingan ekonomi global, memperlambat pertumbuhan ekonomi dunia melalui sentralisasi birokrasi dan ketergantungan kelas bawah, yang secara tak terelakkan diciptakan, dan itu menimbulkan ancaman jangka panjang yang serius terhadap kebebasan dan stabilitas demokrasi. ${ }^{12}$

Berdasarkan fakta-fakta di atas, ada banyak klaim terhadap penerapan negara kesejahteraan yang menggambarkan kinerja buruk di banyak negara. Misalnya, banyak orang yang mengklaim bahwa konsep negara kesejahteraan tidak sesuai dengan kehidupan modern dan mereka ingin sektor swasta mengambil alih tugastugas welfare state tersebut. Sviridoff menyimpulkan bahwa selama tahun-tahun terakhir tahun 1980-an, keyakinan kuat untuk memeriksa ulang the power of welfare state dan memperkuat sektor 
swasta yang ada bermunculan di banyak negara. ${ }^{13}$

Menyikapi kondisi tersebut, sebagaimana telah disinggung di muka, banyak negara di seluruh dunia telah menempuh jalan privatisasi. Di Amerika Serikat, privatisasi mula-mula dikenali sebagai fenomena pada pertengahan dekade 1970-an, pada saat terjadi kecenderungan pemerintah-pemerintah kotapraja (municipal governments) membeli jasa dari perusahaan swasta atas dasar kontrak, diperbincangkan oleh majalah REASON. Hal ini kemudian mendorong berdirinya Local Government Center (LGC) yang dipimpin oleh Mark Frazier dan Robert Poole pada tahun 1976, sebagai think-tank yang mengkhususkan pada penelitian privatisasi. Hasil-hasil kajian LGC tersebut mengilhami tim penulis pidato Presiden Ronald Reagan, dimana beberapa di antaranya telah dijadikan bahan perumusan kebijakan dalam negeri untuk mengembangkan privatisasi di dalam pemerintahannya. ${ }^{14}$

Lain hal dengan Inggris, dimana mantan perdana mentri Margaret Thatcher mengawali kebijakan privatisasi sektor publik pada 1979, sebagai respons atas pergeseran paradigma pengelolaan sektor

\footnotetext{
${ }^{13}$ Ibid., hlm. 50.

${ }^{14}$ Kuntoro Mangkusbroto. (2011). "Privatisasi sebagai Kecenderungan Lingkungan Usaha BUMN". Jurnal Manajemen Teknologi, 10(2): hlm. 116-117.
}

publik sejak Drucker meramalkan "kebangkrutan pemerintahan birokratis". Naluri Thatcher adalah untuk memangkas pemerintah guna efisiensi keuangan negara dan pelayanan birokrasi yang lebih baik lagi. Melalui privatisasi dalam 11 tahun masa kepemimpinannya, pemerintah UK telah menjual lebih dari 40 BUMN utama termasuk British Petroleum, Britoil, Jaguar, British Telecomonications, British Steel, British Airways, dan Roll-Royce ditambah perusahaan yang lebih kecil dan lebih dari 1,25 juta unit perumahan umum. Sampai tahun 1987 penjualan ini menghasilkan 5 miliar pound setahun, yang membantu Thatcher menyeimbangkan empat tahun anggaran terakhirnya. ${ }^{15}$

Privatisasi tahun 1980-an secara keuangan dipicu krisis pada dunia ketiga dan defisit fiskal di banyak negara. Di Inggris, motif keuangan menjadi sangat penting setelah ideologi. Mitos global muncul setelah privatisasi dan deregulasi pada tahun 1980-an disebut sebagai kesuksesan di Inggris. Akibatnya pemerintah negara dunia ketiga dan negara yang memiliki utang banyak mengikuti berbagai kebijakan global. Pemerintah di Inggris menyatakan secara

\footnotetext{
${ }^{15}$ David Osborne dan Peter Plastrik. Banishing Bureaucracy: The Five Strategies for Reinventing Government, diterjemahkan oleh Abdul Rosyid dan Ramelan. (2000). Memangkas Birokrasi: Lima Strategi Menuju Pemerintahan Wirausaha. Jakarta: Penerbit PPM, hlm. 67.
} 
tidak langsung bahwa "privatisasi" dimulai sejak tahun 1979 dan kesuksesan yang dicapai telah memberikan inspirasi pada sejumlah negara sebagai pertimbangan untuk melakukan privatisasi aset negara. ${ }^{16}$ Di berbagai pemerintahan, proses privatisasi telah disebarkan sampai ke pemerintah daerah. Di dalam prakteknya, latar belakang ekonomi dan politik ternyata amat dominan mempengaruhi proses privatisasi itu sendiri. ${ }^{17}$

Di pertengahan tahun 1980-an, perivatisasi telah menjadi global trend dimana negara-negara industri sampai dengan negara-negara di dunia ketiga di benua Afrika, Asia dan Amerika Latin, dan negara-negara di bagian Timur Eropa telah melakukan program privatisasi besar-besaran hampir di seluruh aspek kehidupan ekonomi. Hingga akhir 1980an, privatisasi aset publik telah dilakukan di 82 negara seperti terlihat pada tabel di bawah ini: ${ }^{18}$

\begin{tabular}{|l|c|}
\hline Wilayah Negara & $\begin{array}{c}\text { Jumlah } \\
\text { Negara }\end{array}$ \\
\hline Eropa & 15 \\
Eropa Timur & 7 \\
Amerika Utara & 2 \\
Amerika Latin dan & 14 \\
Karabia & 9 \\
Asia & 5 \\
Pasifik & 24 \\
\hline
\end{tabular}

\footnotetext{
${ }^{16}$ Indra Bastian. (2002). Privatisasi di Indonesia: Teori dan Implementasi. Jakarta: Salemba Empat, hlm. 65 .

${ }^{17}$ Ibid.

${ }^{18}$ Ibid.
}

\begin{tabular}{|l|c|}
\hline Sub-Saharian Afrika & 6 \\
Timur Tengah dan & \\
Afrika Utara & \\
\hline
\end{tabular}

Ikenberry memberikan memberikan penjelasan mengenai alasan teknis pemerintah melakukan privatisasi yang dipelopori oleh Inggris dan Amerika Serikat sebagaimana berikut ini: ${ }^{19}$

1. Respons terhadap Krisis Fiskal: besarnya intervensi pemerintah dalam perekonomian (termasuk di dalamnya pengelolaan BUMN) mengakibatkan beban pemerintah dalam APBN semakin besar, dan salah satu cara memperoleh fresh money adalah dengan melakukan privatisasi atas aset dan perusahaan negara;

2. Meningkatkan Efisiensi; Libenstein dan Prasetiantono menyampaikan bahwa alasan paling dasar dari privatisasi adalah menciptakan efisiensi dalam oprasi BUMN. Beberapa peneliti masalah privatisasi menggunakan terminologi efisiensi sebagai salah satu alasan mendasar prihal urgensi privatisasi perusahaan milik negara;

\footnotetext{
${ }^{19}$ Rian Nugroho Dwidjowijito dan Randy R. Wrihatnolo. (2008). Menejemen Privatisasi BUMN. Jakarta: PT Elex Media Komputindo, hlm. 81.
} 
3. Revitalisasi

Instrumen

Pemerintah; BUMN sebagai salah satu tulang punggung pemerintah, salah satu alat stabilisasi ekonomi dan pemenuhan kebutuhan publik tidak dapat dilaksanakan secara bersamaan. Oleh karena itu, orientasi kepemilikan pemerintah atas perusahaan negara perlu dikaji ulang dalam konteks revitalisasi instrumen pemerintah dalam pembangunan;

4. Membangun Koalisi; privatisasi merupakan salah satu gerakan yang populis dan sebagai salah satu upaya untuk menumbuhkan perekonomian yang kondusif. Meningkatnya peran swasta (nasional dan asing) diyakini akan mampu menciptakan stabilitas ekonomi dan politik sehingga dapat meminimalisasi tekanan pihak luar;

5. Depolitisasi Ekonomi dan Sosial; depolitisasi menjadikan hubungan antara pemerintah dan pihak swasta menjadi sejajar. Pola hubungan yang dibangun diharapkan bersifat simbiosis mutualisme dalam mewujudkan kesejahteraan rakyat.

Penting dipahami bahwa pada dasarnya privatisasi tidak mengandung pengertian tunggal. E.S. Savas, misalnya, memandang privatisasi dari perspektif political-philosophical dan memaknainya sebagai "the act of reducing the role of government, or increasing the role of private sector, in activity or in the ownership of assets." 20 Privatisasi juga dapat didefinisikan dalam pengertian ideologis semata sebagai "a preference for private ownership rather than public ownership." Istilah tersebut akan menyiratkan bahwa orang percaya bahwa perusahaan swasta, yang didasarkan pada mekanisme pasar, lebih baik daripada badan publik, yang didasarkan pada peraturan administratif, dalam soal menyediakan layanan kepada masyarakat umum (konsumen). Dalam hal ideologis, privatisasi juga dapat didefinisikan sebagai bagian dari strategi umum untuk mengubah batas antara sektor publik dan swasta demi mendukung pelayanan yang lebih baik bagi masyarakat yang mana pada akhirnya bermuara pada sentimen anti-negara. ${ }^{21}$ Sementara itu, para pakar ekonomi berusaha untuk menetapkan "the superiority of resource allocation based upon market mechanisms rather than the administrative fiat bureaucracy." Para ekonom mengklaim bahwa efisiensi adalah gagasan utama di balik privatisasi karena mereka percaya bahwa perusahaan

\footnotetext{
${ }^{20}$ Safri Nugraha, Op.Cit., hlm. 14.

21 Ibid.
} 
swasta selalu lebih efisien daripada perusahaan publik. ${ }^{22}$

David Osborne dan Ted Gaebler dalam karya besarnya "Reinventing Government: How the Entrepreneurial Spirit Is Transforming the Public Sector" menyatakan bahwa,

"Swastanisasi hanyalah titik awal yang keliru untuk suatu pembicaraan mengenai peran pemerintah. Pelayanan dapat dikontrakkan atau dialihkan ke sektor swasta, tetapi kepemerintahan (governance) tidak. Kita dapat menswastakan fungsifungsi pengarahan yang terpisah, tetapi tidak keseluruhan proses kepemerintahan. Jika kami melakukan demikian, kami tidak akan mempunyai mekanisme untuk mengambil keputusan kolektif, tak punya cara untuk menetapkan peraturan pasar, tak punya sarana untuk memaksakan peraturan perilaku. Kami akan kehilangan semua rasa keadilan dan sifat mengutamakan kepentingan orang lain ... Bisnis melakukan beberapa hal lebih baik dibanding pemerintah, tetapi pemerintah pun melakukan beberapa hal lebih baik daripada bisnis. ... Demikian juga, pasar swasta menangani banyak tugas lebih baik dibanding administrasi pemerintah - tetapi tidak semua tugas. Pasar swasta untuk pendidikan tinggi lebih berjalan dengan sangat baik, namun tanpa universitas negeri, lembaga pendidikan tinggi negeri untuk masyarakat, dan bantuan keuangan dari negara, banyak orang Amerika

${ }^{22}$ Ibid., hlm. 15. akan kehilangan kesempatan untuk amsuk sekolah tinggi.

Reinventing Governance merupakan gagasan tentang penataan ulang pemerintahan. Reinventing dapat dimaknai sebagai penciptaan kembali birokrasi dengan mendasarkan pada sistem wirausaha, yakni menciptakan organisasi-organisasi dan sistem publik yang memperbarui secara berkelanjutan, memperbaiki kualitasnya, melakukan pembaruan yang bertujuan membuat pemerintah siap menghadapi tantangan yang belum dapat diantisipasi dan menciptakan organisasi yang mampu memperbaiki efektivitasnya di masa mendatang pada saat lingkungan mereka berubah.

\section{Kebijakan Privatisasi di Indonesia}

Pada alenia keempat Pembukaan Undang-Undang Dasar Negara Republik Indonesia Tahun 1945 (UUD NRI Tahun 1945) diikrarkan mengenai tujuan/cita-cita bernegara, yang salah satunya ialah “... untuk memajukan kesejahteraan umum, ...”. Konsekuensi logis dari tujuan bernegara yang demikian itu adalah negara diharuskan untuk ikut serta dalam segala aspek kehidupan rakyatnya,

\footnotetext{
${ }^{23}$ David Osborne dan Ted Gaebler. Reinventing Government: How the Entrepreneurial Spirit is Transforming The Public Sector, diterjemahkan oleh Abdul Rasyid. (1995). Mewirausahakan Birokrasi: Mentransformasi Semangat Wirausaha ke dalam Sektor Publik. Jakarta: Pustaka Binaman Pressindo, hlm. 52-53.
} 
semata-mata untuk menjamin terwujudnya kesejahteraan bagi mereka itu. Konsep negara yang secara aktif turut campur menyejahterakan masyarakat tersebut dikenal secara luas sebagai negara kesejahteraan (welfare state).

Konsep negara kesejahteraan pada kenyataannya mengalami perkembangan dengan melalui banyak varian, namun menurut Utrect lapangan pekerjaan dalam konsep negara kesejahteraan mengutamakan kepentingan seluruh rakyat dengan tegas dan fungsi menyelenggarakan kepentingan umum, seperti kesehatan rakyat, pengajaran, perumahan, pembagian tanah dan sebagainya. $^{24}$ Sebagai langkah konkret dalam menyelenggarakan kepentingan umum tersebut, negara Indonesia dalam konstitusinya menyatakan bahwa segala yang menguasai hajat hidup orang banyak dikuasai oleh negara, sebagaimana bunyi Pasal 33 ayat (2) dan (3) UUD NRI Tahun 1945 sebagai berikut.

(2) Cabang-cabang produksi yang penting bagi negara dan yang menguasai hajat hidup orang banyak dikuasai oleh negara.

(3) Bumi dan air dan kekayaan alam yang terkandung di dalamnya dikuasai oleh negara dan dipergunakan untuk sebesar-besarnya kemakmuran rakyat.

\footnotetext{
${ }^{24}$ Aminuddin Ilmar. (2012). Hak Menguasai Negara dam Privatisasi BUMN. Jakarta: Kencana, hlm. 15-16.
}

Pada Penjelasan UUD Tahun 1945 (sebelum perubahan) terhadap bunyi Pasal 33 itu dimaknai sebagai berikut.

"Perekonomian berdasar atas demokrasi ekonomi, kemakmuran bagi semua orang. Sebab itu cabang-cabang produksi yang penting bagi negara dan yang menguasai hidup orang banyak harus dikuasai oleh negara. Kalau tidak, tampuk produksi jatuh ketangan orang-seorang yang berkuasa dan rakyat yang banyak ditindasinya. Hanya perusahaan yang tidak menguasai hajat hidup orang banyak boleh ada ditangan orang-seorang. Bumi dan air dan kekayaan alam yang terkandung dalam bumi adalah pokok-pokok kemakmuran rakyat. Sebab itu harus dikuasai oleh negara dan dipergunakan untuk sebesar-besar kemakmuran rakyat."

Sementara itu, Emil Salim menjelaskan mengenai pengertian dikuasai oleh negara itu sebagai berikut.

"Negara menguasai bumi, air, dan kekayaan alam yang terkandung dalam bumi dan yang merupakan pokok bagi kemakmuran rakyat dalam melaksanakan hak "menguasai" ini, perlu dijaga supaya sistem yang berkembang tidak menjurus ke arah etatisme. Oleh karena itu hak "menguasai" oleh negara harus dilihat dalam konteks pelaksanaan hak dan kewajiban negara sebagai (1) Pemilik, (2) pengatur, perencana, (4) pelaksana, dan (5) pengawas. Ramuan kelima pokok ini dengan bobot yang berlainan dapat menempatkan negara dalam kedudukannya untuk menguasai lingkungan alam sehingga hak menguasai bisa dilakukan (1) 
dengan memiliki sumber daya alam, (2) tanpa memiliki sumber daya, namun mewujudkan hak menguasai itu melalui jalur pengaturan, perencanaan, dan pengawasan. Dalam sistem ekonomi Pancasila, negara tidak perlu memiliki semua sumber daya alam, tetapi tetap bisa menguasai melalui jalur pengaturan, perencanaan, dan pengawasan."

Dapat disimpulkan bahwa terdapatnya ketentuan dalam konstitusi yang memberi dasar penyelenggaraan cabang-cabang produksi yang penting bagi negara dan yang menguasai hajat hidup orang banyak harus dikuasai oleh negara, tidak berarti memberikan isyarat yang jelas bahwa sistem perekonomian (Indonesia) hanya mengakui adanya penguasaan oleh negara semata, akan tetapi juga mengakui penguasaan oleh koperasi maupun oleh usaha swasta. ${ }^{26}$ Penting dipahami bahwa dalam menjalankan kegiatan usahanya, negara, swasta dan koperasi melaksanakan peran saling mendukung berdasarkan demokrasi ekonomi. $^{27}$

Sebagaimana telah disinggung di muka, dalam kaitan dengan memajukan kesejahteraan bagi seluruh rakyat, negara dirasa perlu untuk meningkatkan

\footnotetext{
${ }^{25}$ Dian Cahya Ningrum. (2004). Politik Hukum Pengaturan Privatisasi dalam Undang-Undang Nomor 19 Tahun 2003 tentang Badan Usaha Milik Negara. Fakultas Hukum Universitas Indonesia: Tesis, hlm. 28.

${ }^{26}$ Aminuddin Ilmar, Op.Cit., hlm. 46.

${ }^{27}$ Penjelasan UU BUMN.
}

penguasaan seluruh kekuatan ekonomi nasional baik melalui regulasi sektoral maupun melalui kepemilikan negara terhadap unit-unit usaha tertentu dengan maksud untuk memberikan manfaat yang sebesar-besarnya bagi kemakmuran rakyat. Penguasaan terhadap unit-unit tertentu oleh negara tersebut dilakukan dengan membentuk badan-badan usaha milik negara (BUMN). BUMN merupakan badan usaha yang seluruh atau sebagian besar modalnya dimiliki oleh negara melalui penyertaan secara langsung yang berasal dari kekayaan negara yang dipisahkan. ${ }^{28}$

Di samping melaksanakan fungsi sosial yakni untuk memberikan manfaat yang sebesar-besarnya bagi kemakmuran rakyat, BUMN juga menempatkan dirinya sebagai salah satu pelaku ekonomi dalam sistem perekonomian nasional bersamasama dengan usaha swasta dan koperasi. Fungsi ganda BUMN itu dapat diamati dari maksud dan tujuan pendirian BUMN sebagaimana tercantum pada rumusan Pasal 2 Undang-Undang Nomor 19 Tahun 2003 tentang Badan Usaha Milik Negara (UU BUMN) berikut ini.

(1) Maksud dan tujuan pendirian BUMN adalah :

a. Memberikan sumbangan bagi perkembangan perekonomian nasional pada

${ }^{28}$ Pasal 1 angka 1 UU BUMN. 
umumnya dan penerimaan negara pada khususnya;

b. Mengejar keuntungan;

c. Menyelenggarakan kemanfaatan umum berupa penyediaan barang dan/atau jasa yang bermutu tinggi dan memadai bagi pemenuhan hajat hidup orang banyak;

d. Menjadi perintis kegiatankegiatan usaha yang belum dapat dilaksanakan oleh sektor swasta dan koperasi;

e. Turut aktif memberikan bimbingan dan bantuan kepada pengusaha golongan ekonomi lemah, koperasi, dan masyarakat.

BUMN pula selanjutnya dibedakan menjadi dua kelompok antara lain Perusahaan Umum (Perum) dan Perusahaan Perseroan (Persero). ${ }^{29}$ Perum adalah BUMN yang seluruh modalnya dimiliki negara dan tidak terbagi atas saham, yang bertujuan untuk kemanfaatan umum berupa penyediaan barang dan/atau jasa yang bermutu tinggi dan sekaligus mengejar keuntungan berdasarkan prinsip pengelolaan perusahaan. ${ }^{30}$ Sementara itu, Persero adalah BUMN yang berbentuk perseroan terbatas yang modalnya terbagi dalam saham yang seluruh atau paling sedikit $51 \%$ (lima puluh satu persen) sahamnya dimiliki oleh Negara Republik Indonesia yang tujuan utamanya mengejar keuntungan. $^{31}$

\footnotetext{
${ }^{29}$ Pasal 9 UU BUMN.

${ }^{30}$ Pasal 1 angka 4 UU BUMN.

${ }^{31}$ Pasal 1 angka 2 UU BUMN.
}

Sebelum berlakunya UU BUMN sebagaimana hari ini, pembagian terhadap badan usaha milik negara telah pula dilakukan lewat Undang-undang Nomor 9 Tahun 1969 tentang Penetapan Peraturan Pemerintah Pengganti Undangundang Nomor 1 Tahun 1969 tentang Bentuk-bentuk Usaha Negara. BUMN pada undang-undang yang lama itu digolongkan menjadi tiga bentuk, yakni Perusahaan Jawatan (Perjan), Perusahaan Umum (Perum), dan Perusahaan Perseroan (Persero). Melalui pembagian BUMN itu ke dalam tiga bentuk usaha tersebut menunjukkan maksud dan tujuan negara untuk memperjelas arah dan sasaran pengelolaan dan penyelenggaraan BUMN. Perjan dikhususkan untuk mengelola dan melayani kebutuhan yang menyangkut hajat hidup orang banyak dan tidak diarahkan untuk memperoleh keuntungan. Sedangkan Perum diarahkan sebagai perusahaan yang dapat menutup operasinya dengan memperoleh keuntungan, tetapi bukan menjadi tujuan utamanya. Lain halnya dengan Persero yang memang diarahkan untuk memperoleh keuntungan dalam arti, karena baiknya pelayanan yang diberikan dan pembinaan organisasi yang baik, efektif, efisien, dan ekonomi secara business zakelijik, cost accounting principles, management effectiveness, dan pelayanan umum yang baik dan 
memuaskan dengan memperoleh surplus atau laba. ${ }^{32}$

Berdasarkan data dari Kementerian BUMN, hingga tahun 2016 tercatat ada total 118 BUMN yang bergerak pada hampir seluruh sektor perekonomian.

Di lain sisi, sebagaimana dialami oleh BUMN di negara-negara lain di seluruh dunia, BUMN di Indonesia juga menghadapi beberapa persoalan. Dikarenakan berbagai kendala, BUMN belum sepenuhnya dapat menyediakan barang dan/atau jasa yang bermutu tinggi bagi masyarakat dengan harga yang terjangkau serta belum mampu berkompetisi dalam persaingan bisnis secara global. Selain itu, karena keterbatasan sumber daya, fungsi BUMN baik sebagai pelopor/perintis maupun sebagai penyeimbang kekuatan swasta besar, juga belum sepenuhnya dapat dilaksanakan. Di lain pihak, perkembangan ekonomi dunia berlangsung sangat dinamis, terutama berkaitan dengan liberalisasi dan globalisasi perdagangan yang telah disepakati oleh dunia internasional seperti kesepakatan mengenai World Trade Organization (WTO), ASEAN Free Trade Area (AFTA), ASEAN Framework Agreement on Service, dan kerjasama ekonomi regional Asia Pacific (Asia Pacific Economic Cooperation/APEC). ${ }^{33}$

Untuk dapat mengoptimalkan perannya dan mampu mempertahankan keberadaannya dalam perkembangan ekonomi dunia yang semakin terbuka dan kompetitif, BUMN perlu menumbuhkan budaya korporasi dan profesionalisme antara lain melalui pembenahan pengurusan dan pengawasannya. Pengurusan dan pengawasan BUMN harus dilakukan berdasarkan prinsipprinsip tata kelola perusahaan yang baik (good corporate governance). ${ }^{34}$

Pentingnya penataan yang berkelanjutan atas pelaksanaan peran BUMN dalam sistem perekonomian nasional, terutama upaya peningkatan kinerja dan nilai (value) perusahaan, telah diamanatkan pula oleh Majelis Permusyawaratan Rakyat (MPR) melalui Ketetapan Nomor IV/MPR/1999 tentang Garis-Garis Besar Haluan Negara Tahun 1999-2004. Tap MPR tersebut menggariskan bahwa BUMN, terutama yang usahanya berkaitan dengan kepentingan umum, perlu terus ditata dan disehatkan melalui restrukturisasi dan bagi BUMN yang usahanya tidak berkaitan dengan kepentingan umum dan

\footnotetext{
${ }^{32}$ Aminuddin Ilmar, Op.Cit., hlm. 85-86.
}

\footnotetext{
${ }^{33}$ Penjelasan Umum UU BUMN.

${ }^{34}$ Penjelasan Umum UU BUMN.
} 
berada dalam sektor yang telah kompetitif didorong untuk privatisasi. ${ }^{35}$

Restrukturisasi menurut Pasal

ayat 11 UU BUMN adalah upaya yang dilakukan dalam rangka penyehatan BUMN yang merupakan salah satu langkah strategis untuk memperbaiki kondisi internal perusahaan guna memperbaiki kinerja dan nilai perusahaan. Pada Pasal 73 ayat (2) UU BUMN disebutkan bahwa,

(2) Tujuan restrukturisasi adalah untuk:

a. meningkatkan kinerja dan nilai perusahaan;

b. memberikan manfaat berupa dividen dan pajak kepada negara;

c. menghasilkan produk dan layanan dengan harga yang kompetitif kepada konsumen; dan

d. memudahkan pelaksanaan privatisasi.

Restrukturisasi tersebut dibedakan menjadi dua macam, yakni restrukturisasi sektoral yang dilakukan untuk menciptakan iklim usaha yang kondusif sehingga tercapai efisiensi dan pelayanan yang optimal dan restrukturisasi perusahaan yang meliputi penataan kembali bentuk badan usaha, kegiatan usaha, organisasi, manajemen, dan keuangan. $^{36}$

Langkah berikutnya ialah privatisasi yang dalam ketentuan Pasal 1 angka 12

\footnotetext{
${ }^{35}$ Penjelasan Umum UU BUMN.

${ }^{36}$ Penjelasan Umum PP Tata Cara Privatisasi Persero
}

UU BUMN dinyatakan sebagai penjualan saham Persero, baik sebagian maupun seluruhnya, kepada pihak lain dalam rangka meningkatkan kinerja dan nilai perusahaan, memperbesar manfaat bagi negara dan masyarakat, serta memperluas pemilikan saham oleh masyarakat. Privatisasi dianggap sebagai langkah penting untuk menumbuhkan budaya korporasi dan profesionalisme yang didasarkan pada prinsip-prinsip tata kelola perusahaan yang baik (good corporate governance). Sofyan A. Djalil, Menteri BUMN (2007-2009), menyatakan bahwa,

"Saat ini, kondisi dan kinerja BUMN dirasakan belum optimal, kegiatan operasional BUMN masih terfragmentasi dan budaya usaha yang birokratis menyebabkan BUMN kurang berorientasi pada pasar, kualitas dan kinerja usaha sehingga produktivitas dan utilitas aset juga sangat rendah. Sebagian BUMN masih memiliki sistem pemasaran dan distribusi yang kurang terkoordinasi dengan baik, khususnya untuk produk ekspor yang terfokus pada komoditas atau industri primer. Di samping itu, sumber daya alam dan tenaga kerja murah dijadikan sebagai keunggulan komparatif (comparative advantage) padahal persaingan saat ini dan ke depan bersifat hiperkompetitif dan menuntut competitive advantage., 37

\footnotetext{
37 Sofyan A. Djalil. "Strategi Dan Kebijakan Pemberdayaan Badan Usaha Milik Negara", diunduh pada tanggal 24 Maret 2018 dari https://muhariefeffendi.wordpress.com/2007/11/14/art ikel-bumn-9/strategi-dan-kebijakan-pemberdayaanbumn/
} 
Penting dipahami bahwa privatisasi bukan semata-mata bermakna sebagai penjualan perusahaan, melainkan menjadi alat dan cara pembenahan BUMN untuk mencapai beberapa sasaran sekaligus, termasuk di dalamnya adalah peningkatan kinerja dan nilai tambah perusahaan, perbaikan struktur keuangan dan manajemen, penciptaan struktur industri yang sehat dan kompetitif, pemberdayaan BUMN yang mampu bersaing dan berorientasi global, penyebaran kepemilikan oleh publik serta pengembangan pasar modal domestik. Privatisasi di Indonesia dilakukan dengan maksud dan tujuan antara lain: i) untuk memperluas kepemilikan masyarakat atas Persero; ii) meningkatkan efisiensi dan produktivitas perusahaan, menciptakan struktur keuangan dan manajemen keuangan yang baik/kuat; iii) menciptakan struktur industri yang sehat dan kompetitif; iv) menciptakan Persero yang berdaya saing dan berorientasi global; v) menumbuhkan iklim usaha, ekonomi makro, dan kapasitas pasar; dan vi) Selain itu, privatisasi dilakukan dengan tujuan untuk meningkatkan kinerja dan nilai tambah perusahaan dan meningkatkan peran serta masyarakat dalam pemilikan saham Persero. $^{38}$
Privatisasi dilakukan dengan memperhatikan prinsip-prinsip transparansi, kemandirian, akuntabilitas, pertanggungjawaban, dan kewajaran. ${ }^{39}$ Secara tegas pula diatur mengenai kriteria perusahaan yang dapat dan tidak dapat diprivatisasi sebagaimana tercantum pada Pasal 76 dan 77 UU BUMN berikut ini.

\section{Pasal 76}

(1) Persero yang dapat diprivatisasi harus sekurangkurangnya memenuhi kriteria: a.industri/sektor usahanya kompetitif; atau b. industri/sektor usaha yang unsur teknologinya cepat berubah.

(2) Sebagian aset atau kegiatan dari Persero yang melaksanakan kewajiban pelayanan umum dan/atau yang berdasarkan Undang-undang kegiatan usahanya harus dilakukan oleh BUMN, dapat dipisahkan untuk dijadikan penyertaan dalam pendirian perusahaan untuk selanjutnya apabila diperlukan dapat diprivatisasi.

Pasal 77
Persero yang tidak dapat
diprivatisasi adalah: a. Persero
yang bidang usahanya berdasarkan
ketentuan peraturan perundang-
undangan hanya boleh dikelola oleh
BUMN;b. Persero yang bergerak di
sektor usaha yang berkaitan dengan
pertahanan dan keamanan negara;
c. Persero yang bergerak di sektor
tertentu yang oleh pemerintah
diberikan tugas khusus untuk
melaksanakan kegiatan tertentu
yang berkaitan dengan kepentingan

\footnotetext{
${ }^{39}$ Pasal 75 UU BUMN.
}

\footnotetext{
${ }^{38}$ Pasal 76 ayat (1) dan (2) UU BUMN.
} 
masyarakat; $d$. Persero yang bergerak di bidang usaha sumber daya alam yang secara tegas berdasarkan ketentuan peraturan perundang-undangan dilarang untuk diprivatisasi.

Yang dimaksud dengan industri/sektor usaha kompetitif adalah industri/sektor usaha yang pada dasarnya dapat diusahakan oleh siapa saja, baik BUMN maupun swasta. Dengan kata lain tidak ada peraturan perundang-undangan (kebijakan sektoral) yang melarang swasta melakukan kegiatan di sektor tersebut, atau tegasnya sektor tersebut tidak semata-mata dikhususkan untuk BUMN. Sementara itu, yang dimaksud dengan industri/sektor usaha yang unsur teknologi cepat berubah adalah industri/sektor usaha kompetitif dengan ciri utama terjadinya perubahan teknologi yang sangat cepat dan memerlukan investasi yang sangat besar untuk mengganti teknologinya. ${ }^{40}$

Dalam amanat UU BUMN disebut bahwa privatisasi dapat dilaksanakan dengan beberapa cara seperti: i) penjualan saham berdasarkan ketentuan pasar modal; ii) penjualan saham langsung kepada investor; dan iii) penjualan saham kepada manajemen dan/atau karyawan yang bersangkutan. ${ }^{41}$ Adapun prosedur privatisasi BUMN menurut UU BUMN dan perinciannya pada Peraturan
Pemerintah Nomor 33 Tahun 2005 tentang Tata Cara Privatisasi Perusahaan Pesero (Perseroan). Pertama, privatisasi harus didahului dengan tindakan seleksi atas perusahaan-perusahaan dan mendasarkan pada kriteria yang ditetapkan dalam Peraturan Pemerintah. Kedua, terhadap perusahaan yang telah diseleksi dan memenuhi kriteria yang telah ditentukan, setelah mendapat rekomendasi dari Menteri Keuangan, selanjutnya disosialisasikan kepada masyarakat setelah dikonsultasikan kepada Dewan Perwakilan Rakyat. Ketiga, hasil dari privatisasi BUMN dialokasikan kepada berbagai bagian yang diatur menurut UU BUMN. Hasil Privatisasi dengan cara penjualan saham milik negara disetor langsung ke Kas Negara. Hasil Privatisasi yang dimaksud adalah hasil divestasi saham milik negara. Sedangkan bagi penjualan saham baru, hasilnya disetorkan ke kas perusahaan. Bagi hasil privatisasi anak perusahaan BUMN, hasil privatisasinya dapat ditetapkan sebagai deviden interim. Hasil Privatisasi tersebut haruslah hasil bersih setelah dikurangi biaya-biaya pelaksanaan Privatisasi. Biaya pelaksanaan privatisasi harus memperhatikan prinsip kewajaran, transparansi, dan akuntabilitas.

\footnotetext{
${ }^{40}$ Penjelasan Pasal 76 ayat (1) UU BUMN.

${ }^{41}$ Pasal 78 UU BUMN.
} 


\section{Penutup}

\section{Simpulan}

Berdasarkan uraian mengenai konsep kebijakan privatisasi di Indonesia sebagaimana di atas, maka dapat disimpulkan beberapa hal penting sebagai berikut: Privatisasi tidak mengandung pengertian tunggal. Privatisasi dapat dilihat dari berbagai perspektif, seperti perspektif political-philosophical yang memaknainya sebagai "the act of reducing the role of government, or increasing the role of private sector, in activity or in the ownership of assets." Privatisasi juga dapat didefinisikan dalam pengertian ideologis semata sebagai " $a$ preference for private ownership rather than public ownership." Sementara itu, para pakar ekonomi berusaha untuk menetapkan "the superiority of resource allocation based upon market mechanisms rather than the administrative fiat bureaucracy." Para ekonom mengklaim bahwa efisiensi adalah gagasan utama di balik privatisasi karena mereka percaya bahwa perusahaan swasta selalu lebih efisien daripada perusahaan publik.

Ketentuan dalam UUD NRI Tahun 1945 memberi dasar bahwa penyelenggaraan cabang-cabang produksi yang penting bagi negara dan yang menguasai hajat hidup orang banyak harus dikuasai oleh negara dilakukan dengan membentuk badan-badan usaha milik negara (BUMN). BUMN merupakan badan usaha yang seluruh atau sebagian besar modalnya dimiliki oleh negara melalui penyertaan secara langsung yang berasal dari kekayaan negara yang dipisahkan. Di samping melaksanakan fungsi sosial yakni untuk memberikan manfaat yang sebesar-besarnya bagi kemakmuran rakyat, BUMN juga menempatkan dirinya sebagai salah satu pelaku ekonomi dalam sistem perekonomian nasional bersama-sama dengan usaha swasta dan koperasi. Untuk dapat mengoptimalkan perannya dan mampu mempertahankan keberadaannya dalam perkembangan ekonomi dunia yang semakin terbuka dan kompetitif, BUMN perlu menumbuhkan budaya korporasi dan profesionalisme antara lain melalui pembenahan pengurusan dan pengawasannya. Pengurusan dan pengawasan BUMN harus dilakukan berdasarkan prinsip-prinsip tata kelola perusahaan yang baik (good corporate governance), yang mana salah satu upayanya adalah dengan melakukan privatisasi. Sesuai ketentuan UU BUMN, privatisasi merupakan penjualan saham Persero, baik sebagian maupun seluruhnya, kepada pihak lain dalam rangka meningkatkan kinerja dan nilai perusahaan, memperbesar manfaat bagi negara dan masyarakat, serta memperluas pemilikan saham oleh masyarakat. 


\section{Saran}

Adapun saran yang dapat diberikan terkait kebijakan privatisasi di Indonesia ialah bahwa penting untuk melihat kebijakan privatisasi atas BUMN yang ditempuh pemerintah secara komprehensif, yakni mulai dari sistem perekonomian nasional yang berlandaskan Pancasila dan konstitusi hingga kepada kebutuhan melakukan privatisasi sebagai upaya untuk mengoptimalkan kualitas pelayanan dan peningkatan keuntungan dari produk atau jasa yang dihasilkan oleh BUMN. Hal demikian itu berlaku baik bagi pemerintah selaku policy maker, perusahaan swasta selaku pihak yang dijadikan mitra kegiatan privatisasi BUMN, dan masyarakat sebagai warga negara yang memiliki hak akan kualitas pelayanan yang baik.

\section{DAFTAR PUSTAKA}

\section{Buku-buku}

Bastian, Indra. (2002). Privatisasi di Indonesia: Teori dan Implementasi. Jakarta: Salemba Empat.

Departemen Hukum dan HAM RI, Badan Pembinaan Hukum Nasional. (2005). Analisa dan Evaluasi Hukum tentang Privatisasi Badan Usaha Milik Negara (BUMN). Jakarta: BPHN RI.

Dwidjowijito, Rian Nugroho dan Wrihatnolo, Randy R. (2008). Menejemen Privatisasi BUMN. Jakarta: PT Elex Media Komputindo.
Ilmar, Aminuddin. (2012). Hak Menguasai Negara dam Privatisasi BUMN. Jakarta: Kencana.

Marbun, SF., dkk. (2001). Dimensi-dimensi Pemikiran Hukum Administrasi Negara. Yogyakarta: UII Press.

Nugraha, Safri. (2004). Privatisation of State Enterprises in the 20th Century: A Step Forwards or Backwards?. Jakarta: Institute For Law and Economics Studies Faculty of Law University of Indonesia.

Osborne, David dan Gaebler, Ted. Reinventing Government: How the Entrepreneurial Spirit is Transforming The Public Sector, diterjemahkan oleh Rasyid, Abdul. Mewirausahakan Birokrasi: Mentransformasi Semangat Wirausaha ke dalam Sektor Publik. Jakarta: Pustaka Binaman Pressindo.

Osborne, David dan Plastrik, Peter. Banishing Bureaucracy: The Five Strategies for Reinventing Government, diterjemahkan oleh Rosyid, Abdul dan Ramelan. (2000). Memangkas Birokrasi: Lima Strategi Menuju Pemerintahan Wirausaha. Jakarta: Penerbit PPM.

R. Ridwan H. (2011). Hukum Administrasi Negara. Jakarta: Raja Grafindo Persada.

Sibuea, Hotma P. (2010). Asas Negara Hukum, Peraturan Kebijakan, dan Asas-asas Umum Pemerintahan yang Baik. Jakarta: Penerbit Erlangga.

\section{Majalah Ilmiah}

Mangkusbroto, Kuntoro. (2011). "Privatisasi sebagai Kecenderungan Lingkungan Usaha BUMN". Jurnal Manajemen Teknologi, 10(2).

Maro'ah, Siti. (2008). "Kebijakan Privatisasi dan Pengaruhnya dalam Perekonomian Makro Indonesia". Balance Economics, 
Bussiness, Management and Accounting Journal, 5(9).

Shirley, Mary M. (1992). "The What, Why, and How of Privatization: A World Bank Perspective". Fordham Law Review, 60.

\section{Sumber yang Tidak Diterbitkan}

Ningrum, Dian Cahya. (2004). Politik Hukum Pengaturan Privatisasi dalam Undang-Undang Nomor 19 Tahun 2003 tentang Badan Usaha Milik Negara. Fakultas Hukum Universitas Indonesia: Tesis.

\section{Internet}

Djalil, Sofyan A. Strategi Dan Kebijakan Pemberdayaan Badan Usaha Milik Negara, diunduh pada tanggal 24 Maret 2018 dari https://muhariefeffendi.wordpress.com/ 2007/11/14/artikel-bumn-9/strategidan-kebijakan-pemberdayaan-bumn/

Harvard Business Review, Does Privatization Serve The Public Interest?, diunduh pada tanggal 18 Maret 2018 dari https://hbr.org/1991/11/doesprivatization-serve-the-public-interest

Kementerian Badan Usaha Milik Negara, Statistik Jumlah BUMN, diunduh pada tanggal 24 Maret 2018 dari http://www.bumn.go.id/halaman/0$\underline{\text { Statistik-Jumlah-BUMN }}$

The Guardian, How Privatization Could Spell The End Of Democracy, diunduh pada tanggal 18 Maret 2018 dari https://www.theguardian.com/technolo gy/2017/jun/21/privatizing-publicservices-trump-democracy
The Telegraph, Margaret Thatcher: one policy that led to more than 50 companies being sold or privatised, diunduh pada tanggal 18 Maret 2018 dari

https://www.telegraph.co.uk/finance/co mment/alistair-

osborne/9980292/Margaret-Thatcherone-policy-that-led-to-more-than-50companies-being-sold-orprivatised.html

\section{Peraturan Perundang-undangan}

Ketetapan Majelis Permusyawaratan Rakyat Nomor IV/MPR/1999 tentang GarisGaris Besar Haluan Negara Tahun 1999-2004

Peraturan Pemerintah Nomor 33 Tahun 2005 tentang Tata Cara Privatisasi Perusahaan Peseroan (Perseroan) (Lembaran Negara Republik Indonesia Tahun 2005 Nomor 115, Tambahan Lembaran Negara Republik Indonesia Nomor 4528)

Undang-Undang Dasar Negara Republik Indonesia Tahun 1945

Undang-undang Nomor 9 Tahun 1969 tentang Penetapan Peraturan Pemerintah Pengganti Undang-undang Nomor 1 Tahun 1969 tentang Bentukbentuk Usaha Negara (Lembaran Negara Tahun 1969 Nomor 16, Tambahan Lembaran Negara Nomor 2890) menjadi Undang-undang (Lembaran Negara Republik Indonesia Tahun 1969 Nomor 40, Tambahan Lembaran Negara Nomor 2904)

Undang-Undang Nomor 19 Tahun 2003 tentang Badan Usaha Milik Negara (Lembaran Negara Republik Indonesia Tahun 2003 Nomor 70, Tambahan Lembaran Negara Nomor 4297) 